\title{
Evaluation of Groundnut Cultivars under Late Sown Conditions
}

\author{
D. Sampath Kumar* \\ Agricultural Research Station, ANGRAU, Kadiri, India \\ *Corresponding author
}

\section{A B S T R A C T}

\begin{tabular}{l} 
Ke y w o r d s \\
Groundnut \\
Cultivars under \\
Late Sown \\
Conditions \\
\hline Article Info \\
\hline $\begin{array}{l}\text { Accepted: } \\
10 \text { November } 2020 \\
\text { Available Online: } \\
10 \text { December } 2020\end{array}$ \\
\hline
\end{tabular}

Field experiment was conducted at Agricultural Research Station, Kadiri, ANGRAU to study the influence of sowing windows on growth and yield of groundnut genotypes under rainfed conditions during Kharif season of 2011-12, 2012-13 and 2013-14 on sandy loam soil. Four groundnut genotypes viz., Kadiri-4, Kadiri-5, Kadiri-6 and Vemana were evaluated under four sowing windows viz., (D1: onset of monsoon, D2: 7 days after onset of monsoon, D3: 14 days after onset of monsoon, D4: 21 days after onset of monsoon). The experiment was laid out in Split plot Design and replicated thrice. Pooled results over three years of study revealed that among four varieties studied mean pod yield of K-4, K-6 and Vemana are at par compared to K-5. Among different dates of sowing, pod yields were significantly higher with sowing upto first week of August (D1 \& D2) and further delay in sowing time significantly reduced the pod yields. Pod yields of all the varieties reduced with delay in sowing time except K-4. Its pod, haulm yield increased with delay in sowing time. This reveals that K-4 seems to be promising for delayed sowings.

\section{Introduction}

Groundnut is an important oilseed crop of India, occupying about 7.0 million hectare area, scattered over 260 districts of 12 states. Groundnut shall continue to be an important oil seed crop for the semi-arid regions if the projected demand of oils and fats has to be mat with sustainability. In dry land agriculture, farmers have limited choice for sowing time, but in irrigated situation sowing time is one of the most important nonmonetary inputs affecting yield of crops (Sardana and Kandhol, 2007). Kabadagi and Bala (2010) worked together in different climatic conditions including present one and sowing time and genotypes responds very well to variant climatic conditions. In southern parts of India, onset of S.W. Monsoon is usually delayed and farmers could not sow the Groundnut crop before $2^{\text {nd }}$ week of July. Sowings will be taken up even in $1^{\text {st }}$ week of August with the receipt of meagre rains which resulted poor yields. Selection of suitable variety for such late sown conditions may avoid the complete crop loss. Hence this experiment is proposed.

\section{Materials and Methods}

The field experiment was conducted with four varieties (K-4, Kadiri-5, Kadiri-6 and Vemana) sown under four dates (onset of monsoon, 7 days after onset of monsoon, 14 
days after onset of monsoon, 21 days after onset of monsoon) in split plot design with 3 replications during kharif, 2011 to 2013 under rainfed situation at Agricultural research station, Kadiri. The soil of the experimental site was sandy loam and nutrients were applied @ 20-40-50 kg NPK ha ${ }^{-1}$ in the form of urea, SSP and MOP respectively along with $10 \mathrm{t}$ of farm yard manure. Biometric observations were recorded by selected five plants from each plot randomly and marked with proper rotations. These plants were harvested at maturity separately for assessing individual plant yield. The growth parameters and yield parameters were studied. Pod and haulm yield was recorded from the net plot discarding $60 \mathrm{~cm}$ plot at all four sides. The data recorded on various parameters of crop was subjected to statistical scrutiny by the method of analysis of variance as outlined by Panse and Sukhatme (1985). Statistical significance was tested by ' $F$ ' value at 5 per cent level of probability and wherever the ' $F$ ' value was found significant, critical difference (CD) was worked out at 5 per cent level of probability and the values are furnished. The treatment difference that were non significant are denoted as NS (Table 14).

\section{Results and Discussion}

\section{Kharif, 2011}

Four cultivars namely K-4, K-5, K-6 and Vemana were evaluated under four dates of sowing. Among different cultivars, Vemana recorded highest mean pod yield $\left(604 \mathrm{~kg} \mathrm{ha}^{-1}\right)$ which was significantly superior to K-5 but on par with K-4 and K-6. Yield attributes also followed the similar trend. Among the different dates of sowing, except K-4, all the cultivars resulted higher pod and haulm yields with D1 and decreased with delay in the sowing time. The rate of decrease in yield due to delayed sowing is more with Vemana compared to K-6. Pod yield, haulm yield and yield attributes of Vemana, K-6 and K-5 didn't differ significantly due to delayed sowing up to 11-8-2006 and later on decreased significantly. The trend of K-4 is quite dissimilar. Its pod yield, haulm yield and yield attributes were increased with delay in sowing time, D4 being the maximum. Hence, this experiment reveals that K-4 seems to be promising for delayed sowings. However, K-6 appears to be relatively stable cultivar even under delayed sowings and Vemana showing its drought tolerance with its highest mean pod yield.

\section{Kharif, 2012}

Different cultivars under different dates of sowing exerted significant influence on the economical yield and yield attributes of rainfed groundnut. Pod yield of K-5, K-6 and Vemana significantly decreased with delay in sowing time from 22-7-2012 onwards. The rate of decrease in pod and haulm yield is observed to be same in all varieties except $\mathrm{K}$ 4. The trend of K-4 variety is quite dissimilar. Its pod, haulm yield increased with delay in sowing time. This reveals that K-4 seems to be promising for delayed sowings. Higher 100 pod weight, 100 kernel weight was with K-6 variety sown in first date of sowing and the shelling \% and SMK\% of different varieties did not influenced significantly due to sowing time.

\section{Kharif, 2013}

Among varieties, Vemana has recorded significantly higher mean pod yield $(739 \mathrm{~kg}$ $\mathrm{ha}^{-1}$ ), which was on par with K-4 and K-6. Mean pod yield over different dates decreased with delay in sowing time, the highest being with D1 (800 kg ha-1), which was on par with D2 and significantly superior over D3 and D4. 
Table.1 Pod and haulm yield of groundnut cultivars as influenced by different sowing dates

\begin{tabular}{|c|c|c|c|c|c|c|c|c|}
\hline \multirow[t]{2}{*}{ Treatments } & \multicolumn{4}{|c|}{ Pod Yield (kg ha $\left.{ }^{-1}\right)$} & \multicolumn{4}{|c|}{ Haulm yield $\left(\mathrm{kg} \mathrm{ha}^{-1}\right)$} \\
\hline & 2011 & 2012 & 2013 & $\begin{array}{l}\text { Pooled } \\
\text { Mean }\end{array}$ & 2011 & 2012 & 2013 & $\begin{array}{c}\text { Pooled } \\
\text { Mean }\end{array}$ \\
\hline \multicolumn{9}{|l|}{ Main Plots: } \\
\hline V1: K-4 & 591 & 963 & 689 & 748 & 997 & 1288 & 1344 & 1210 \\
\hline V2: K-5 & 364 & 957 & 607 & 643 & 984 & 1618 & 1753 & 1452 \\
\hline V3: K-6 & 515 & 959 & 660 & 711 & 1060 & 1372 & 1760 & 1397 \\
\hline V4: Vemana & 604 & 931 & 739 & 758 & 1712 & 1715 & 1826 & 1751 \\
\hline CV \% & 16.5 & 26.3 & 18.3 & 16.1 & 24.1 & 10.1 & 26.1 & 17.5 \\
\hline SEm \pm & 49.0 & 102.2 & 51.0 & 44.1 & 114.9 & 61.9 & 128.8 & 94.7 \\
\hline CD at $5 \%$ & 120 & NS & 126 & 108 & 282 & 151 & 318 & 232 \\
\hline \multicolumn{9}{|l|}{ Sub Plots: } \\
\hline D1: onset of monsoon & 545 & 1041 & 800 & 795 & 1290 & 1462 & 1845 & 1532 \\
\hline D2: 7 days to D1 & 515 & 998 & 774 & 762 & 1177 & 1854 & 1642 & 1558 \\
\hline D3: 14 days to D1 & 534 & 864 & 567 & 655 & 1158 & 1323 & 1628 & 1370 \\
\hline D4: 21 days to D1 & 480 & 907 & 553 & 647 & 1077 & 1354 & 1569 & 1333 \\
\hline CV \% & 17.3 & 24.5 & 19.0 & 18.6 & 16.2 & 11.1 & 18.2 & 15.2 \\
\hline $\operatorname{SEm} \pm$ & 36.6 & 95.1 & 53.4 & 50.3 & 77.3 & 67.8 & 57.5 & 62.2 \\
\hline CD at $5 \%$ & NS & NS & 132 & 123 & 159 & 140 & 142 & 152 \\
\hline Interaction (VxD) & 151 & NS & 148 & 168 & 318 & 280 & 322 & 218 \\
\hline
\end{tabular}

Table.2 Number of pods/plant and yield attributes of groundnut cultivars as influenced by different sowing dates

\begin{tabular}{|c|c|c|c|c|c|c|c|c|c|c|c|c|}
\hline \multirow[t]{2}{*}{ Treatments } & \multicolumn{4}{|c|}{ Number of pods/plant } & \multicolumn{4}{|c|}{ Hundred pod weight } & \multicolumn{4}{|c|}{ Shelling \% } \\
\hline & 2006 & 2007 & 2008 & $\begin{array}{c}\text { Pooled } \\
\text { Mean }\end{array}$ & 2006 & 2007 & 2008 & $\begin{array}{c}\text { Pooled } \\
\text { Mean }\end{array}$ & 2006 & 2007 & 2008 & $\begin{array}{c}\text { Pooled } \\
\text { Mean }\end{array}$ \\
\hline \multicolumn{13}{|l|}{ Main Plots: } \\
\hline V1: K-4 & 9.4 & 11.1 & 9.9 & 10.1 & 71.0 & 73.1 & 59.1 & 67.7 & 71.7 & 75.5 & 65.9 & 71.0 \\
\hline V2: K-5 & 7.4 & 12.9 & 7.7 & 9.3 & 70.4 & 70.8 & 58.5 & 66.6 & 66.8 & 74.8 & 69.1 & 70.2 \\
\hline V3: K-6 & 8.2 & 11.3 & 8.0 & 9.2 & 81.6 & 85.8 & 66.8 & 78.1 & 68.6 & 76.0 & 69.4 & 71.3 \\
\hline V4: Vemana & 11.0 & 11.9 & 9.2 & 10.7 & 71.2 & 71.3 & 60.5 & 67.7 & 72.0 & 77.5 & 69.6 & 73.0 \\
\hline $\mathrm{CV} \%$ & 19.0 & 25.2 & 18.6 & 21.8 & 8.7 & 12.3 & 9.2 & 11.6 & 3.4 & 4.8 & 5.2 & 6.7 \\
\hline SEm \pm & 0.85 & 1.21 & 1.1 & 0.97 & 2.61 & 3.83 & 2.51 & 2.91 & 0.96 & 1.49 & 1.13 & 1.05 \\
\hline CD at $5 \%$ & 2.1 & 3.0 & NS & NS & 6.4 & 9.4 & 6.2 & 7.2 & 2.4 & 3.6 & 2.8 & 2.6 \\
\hline \multicolumn{13}{|l|}{ Sub Plots: } \\
\hline $\begin{array}{l}\text { D1: onset of } \\
\text { monsoon }\end{array}$ & 10.2 & 14.2 & 9.3 & 11.2 & 76.2 & 82.2 & 64.9 & 74.4 & 70.5 & 75.0 & 69.0 & 71.5 \\
\hline $\begin{array}{l}\text { D2: } 7 \text { days to } \\
\text { D1 }\end{array}$ & 9.0 & 15.1 & 9.0 & 11.0 & 74.4 & 77.1 & 61.0 & 70.8 & 70.3 & 75.1 & 68.7 & 71.4 \\
\hline $\begin{array}{l}\text { D3: } 14 \text { days to } \\
\text { D1 }\end{array}$ & 8.6 & 9.1 & 8.9 & 8.9 & 71.7 & 72.0 & 59.9 & 67.9 & 70.1 & 77.5 & 68.8 & 72.1 \\
\hline $\begin{array}{l}\text { D4: } 21 \text { days to } \\
\text { D1 }\end{array}$ & 8.2 & 8.8 & 7.6 & 8.2 & 71.8 & 69.7 & 59.0 & 66.8 & 68.1 & 76.2 & 67.5 & 70.6 \\
\hline CV \% & 20.3 & 16.9 & 18.6 & 17.8 & 8.8 & 9.5 & 11.6 & 10.6 & 2.5 & 5.1 & 16.5 & 13.6 \\
\hline $\operatorname{SEm} \pm$ & 0.75 & 0.82 & 0.89 & 0.77 & 2.64 & 2.96 & 1.70 & 2.54 & 0.72 & 1.59 & 0.93 & 0.73 \\
\hline CD at $5 \%$ & 1.5 & 1.7 & NS & 1.9 & 5.5 & 6.1 & 4.2 & 6.3 & 1.5 & 3.3 & NS & NS \\
\hline $\begin{array}{c}\text { Interaction } \\
\text { (VxD) }\end{array}$ & 3.1 & 3.4 & 2.6 & 2.9 & 10.9 & 12.2 & 5.4 & 7.1 & 3.0 & 6.6 & 2.9 & 3.1 \\
\hline
\end{tabular}


Table.3 Two way table showing the pod yield of groundnut cultivars as influenced by different sowing dates (Pooled for 3 years)

\begin{tabular}{|c|c|c|c|c|c|}
\hline & D1 & D2 & D3 & D4 & Mean \\
\hline V1: K-4 & 644 & 755 & 744 & 848 & 748 \\
\hline V2: K-5 & 799 & 675 & 565 & 530 & 642 \\
\hline V3: K-6 & 811 & 798 & 607 & 631 & 712 \\
\hline V4: Vemana & 927 & 821 & 706 & 580 & 759 \\
\hline Mean & 795 & 762 & 656 & 647 & -- \\
\hline
\end{tabular}

Table.4 Reduction in pooled pod yield (\%) of groundnut cultivars due to delay in sowing time

\begin{tabular}{|l|c|c|c|c|}
\hline & D1 & D2 & D3 & D4 \\
\hline V1: K-4 & -- & +17.2 & +15.5 & +31.7 \\
\hline V2: K-5 & -- & -15.5 & -29.3 & -33.7 \\
\hline V3: K-6 & -- & -1.6 & -25.2 & -22.2 \\
\hline V4: Vemana & -- & -11.4 & -23.6 & -37.4 \\
\hline Mean & -- & -4.2 & 17.5 & -18.6 \\
\hline
\end{tabular}

The interaction effect is also significant. Pod yield of all the varieties is on par with first and second date of sowing, higher being with second date for K-4 and Vemana while, with first date with K-5 and Vemana. Highest mean haulm yield was recorded with K-4 at first date of sowing. Number pods per plant did not varied significantly either due to dates of sowing or due to varieties. Higher hundred pod \& kernel weight, shelling percentage and SMK was with K-6 at first date of sowing. Incidence of PSND also significantly varied due to varieties and dates of sowing. PSND incidence was significantly higher with earlier sowings and decreased with delay in sowing time. Among varieties, highest and lowest incidence was observed with $\mathrm{K}-5$ and Vemana respectively.

\section{Pooled results and conclusions}

Pooled results over three years of study revealed that among four varieties studied mean pod yield of K-4, K-6 and Vemana are at par compared to K-5. Among different dates of sowing, pod yields were significantly higher with sowing upto first week of August (D1 \& D2) and further delay in sowing time significantly reduced the pod yields. The interaction effect is also significant. Pod yield of all the varieties is on par with first and second date of sowing, higher being with second date. Pod yields of all the varieties reduced with delay in sowing time except K4. Its pod, haulm yield increased with delay in sowing time. This reveals that K-4 seems to be promising for delayed sowings. Incidence of PSND also significantly varied due to varieties and dates of sowing. PSND incidence was significantly higher with earlier sowings and decreased with delay in sowing time. Among varieties, highest and lowest incidence was observed with K-5 and Vemana respectively. Hence from this study, it can be concluded that second fort night of July is the best time for Kharif groundnut in Kadiri region with Vemana, K-4 and K-6 varieties. K-4 is the promising variety for late sown conditions. This might be due to the combination of genetic character and also the 
optimum weather conditions during the crop growth. Similar results were reported by Mohite et al., (2017).

\section{References}

Sardana V and Kandhola SS .2007. Productivity of semi-spreading and bunch type varieties of groundnut as influenced by sowing dates. An Op. Acc. J. 5:1-3.

Kabadagi CB and Setty RA. 2010. Growth characters and yield of groundnut genotypes as influenced by levels of NPK and growth regulators. Res. on Crops. 11(3):697-700.

Panse, V.G and Sukhatme, P.V.1985. Statistical Methods for Agricultural workers. ICAR, New Delhi. pp.100174.

Mohite, U. A., Mohite, A. B and Jadhav, Y. R. 2017. Effect of sowing windows on growth and yield of groundnut varieties during Kharif season. Contemporary Research in India. 7: 189-192

\section{How to cite this article:}

Sampath Kumar, D. 2020. Evaluation of Groundnut Cultivars under Late Sown Conditions. Int.J.Curr.Microbiol.App.Sci. 9(12): 863-867. doi: https://doi.org/10.20546/ijcmas.2020.912.103 